\title{
Human activity and damaging landslides and floods on Madeira Island
}

\author{
D. Baioni \\ Dipartimento di Scienze della Terra, Università degli studi di Parma, Campus Universitario, Via delle Scienze \\ 43100 Parma (PR), Italy
}

Received: 3 August 2011 - Accepted: 26 September 2011 - Published: 15 November 2011

\begin{abstract}
Over the last few decades, the island of Madeira has become an important offshore tourism and business center, with rapid economic and demographic development that has caused changes to the landscape due to human activity. In Madeira's recent history, there has been an increase over time in the frequency of occurrence of damaging landslide and flood events. As a result, the costs of restoration work due to damage caused by landslide and flood events have become a larger and larger component of Madeira's annual budget. Landslides and floods in Madeira deserve particular attention because they represent the most serious hazard to human life, to property, and to the natural environment and its important heritage value.

The work reported on in this paper involved the analysis of historical data regarding damaging landslide and flood events on Madeira (in particular from 1941 to 1991) together with data on geological characteristics, topographic features, and climate, and from field observations. This analysis showed that the main factor triggering the occurrence of damaging landslide and flood events is rainfall, but that the increase in the number of damaging events recorded on Madeira Island, especially in recent times, seems to be related mostly to human activity, specifically to economic development and population growth, rather than to natural factors.
\end{abstract}

\section{Introduction}

The island of Madeira is part of an archipelago of volcanic origin situated in the Atlantic Ocean (from $32^{\circ} 23^{\prime} \mathrm{N}$ to $33^{\circ} 07^{\prime} \mathrm{N}$ and from $16^{\circ} 15^{\prime} \mathrm{W}$ to $17^{\circ} 15^{\prime} \mathrm{W}$ ) approximately $900 \mathrm{~km}$ southwest of Portugal and $700 \mathrm{~km}$ west of the coast

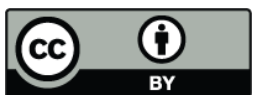

Correspondence to: D. Baioni (davide.baioni@unipr.it) of Morocco (Fig. 1). Madeira is the main island of the group, measuring $58 \mathrm{~km}$ in length and having a maximum width of $23 \mathrm{~km}$, with a surface area of $739 \mathrm{~km}^{2}$.

The island of Madeira is part of Portugal, but it is an autonomous region with its own government that can freely discuss and regulate many matters regarding its own territory.

Madeira has a resident population of approximately 245000 concentrated almost exclusively in the coastal areas, predominantly on the south side of the island where most of the larger towns are located and where most of the economic activity of Madeira takes place. The southeastern part of the island, in particular the coastal strip between the capital, Funchal, and the city of Machico, is very densely populated. Funchal is currently one of the most densely populated areas in the entire European Community (1338 inhabitants per $\mathrm{km}^{2}$ ), with an annual growth rate of $4 \%$, which is rapidly increasing.

Human activity on the island of Madeira dates back to the end of the fifteenth century, when the first pioneers began to settle there, cultivating sugar cane and building the first village, Funchal, which would later become the capital city. Up to the end of the nineteenth century, Madeira did not have a port and was not known as a tourist destination.

Building construction that interfered with the natural environment of Madeira began during the twentieth century when its main port (Funchal) became an essential supply station for ships en route to Africa and South America. The strategic and commercial importance of becoming an essential stopover point for maritime traffic encouraged residents to build artificial canals called "levadas", which are still present today, to divert natural water flows from the north side of the island, which is much rainier and not very built up, to the southern part of the island, which is undergoing constant expansion. The growth in human activity on Madeira began during the nineteenth century but intensified only during the second half of the twentieth century.

Published by Copernicus Publications on behalf of the European Geosciences Union. 


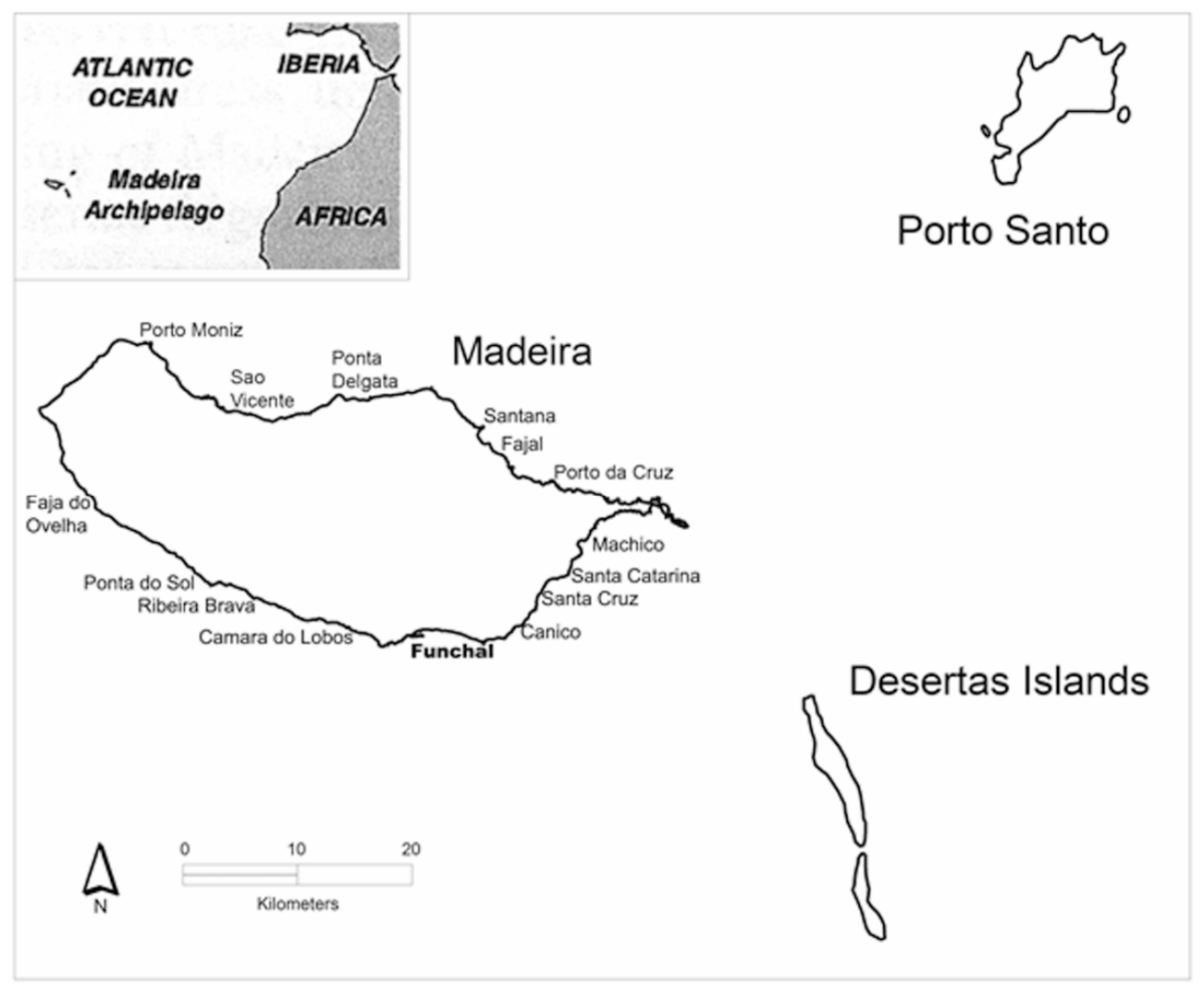

Fig. 1. Location map of Madeira Archipelago.

In the last few decades, Madeira has become an important tourist destination, which has led to an explosion of building activity in a very short space of time, involving both hotels and their associated infrastructure. The scarcity of suitable space for building due to the topography of the island has tended to force development into unsuitable areas, causing profound changes to the landscape.

Over the last few decades, Madeira has seen rapid economic growth.

Madeira's recent history shows a clear increase in the cost of restoration work, protective measures, and damage caused by landslides and floods, costs that have become a larger and larger component of Madeira's annual budget.

On Madeira, natural geomorphological processes are particularly active due to the island's geographical location and climatic characteristics.

The aim of this study is to explore the relationship between the occurrence of damaging landslides and floods on Madeira and the intensity of recent human activity and development, and to determine whether a cause-effect relationship may exist.

\section{Study area}

\subsection{Geology and geomorphology}

Madeira Island was formed by volcanic activity in the Miocene period; its geology is illustrated in Fig. 2 (after Zbyszewski et al., 1975). The formation of Madeira began in the Middle Miocene with explosive submarine eruptions consisting mainly of basaltic pyroclasts (B1 complex). After a very long pause, further volcanic activity formed an extensive complex made up of explosive and effusive material (B2 complex). After another interruption, renewed volcanic activity formed a basaltic complex where flows dominate over pyroclastic materials (B3 complex). The B3 complex was then successively overlaid by thick basaltic flows attributed to fissural volcanism (B4 complex); during the last volcanic stage, the eruptions filled existing valleys in the northwestern part of the island (B5 complex). The central region has the characteristic of a volcanic rift (Geldmacher and Hoernle, 2000) with swarms of vertical dikes, normal faults, graben structures, and cinder cones, all parallel to the E-W trending long axis of the island.

The island is mountainous, especially in the central part (Fig. 3), with altitudes that reach $1860 \mathrm{~m}$ a.s.l. The average altitude is $700 \mathrm{~m}$ and $90 \%$ of the island is over $500 \mathrm{~m}$ 


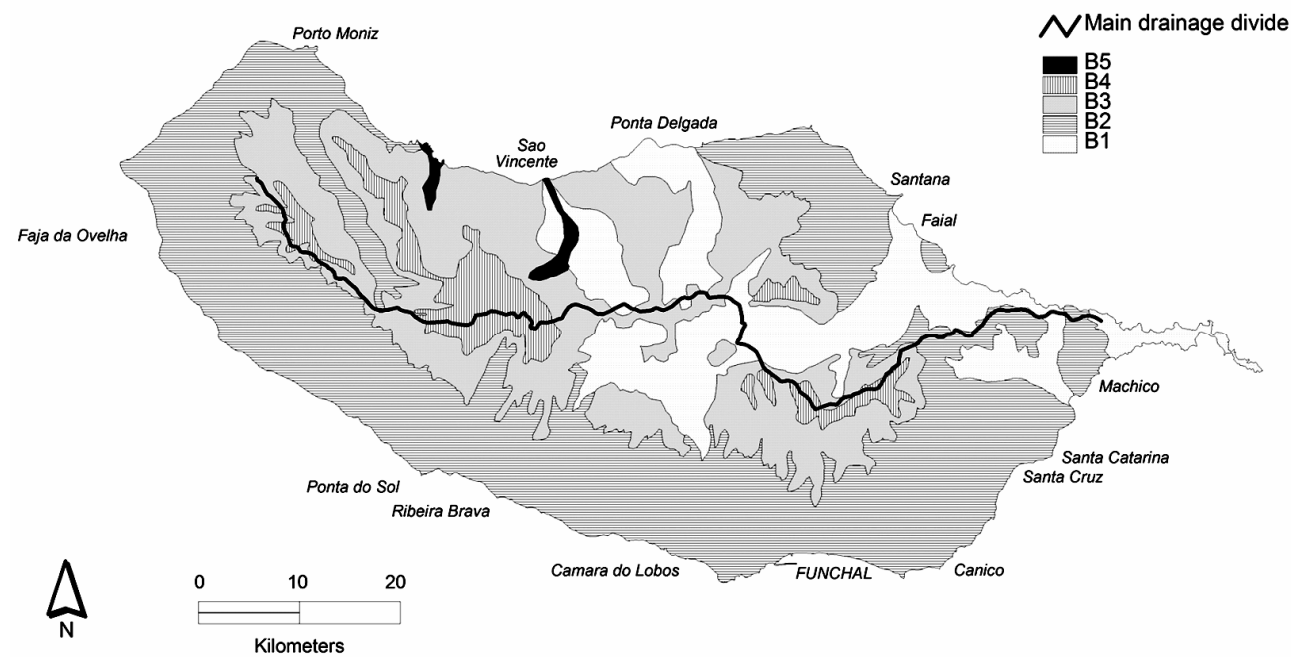

Fig. 2. Geology of Madeira Island (after Zbyszewski et al., 1975). (B1) basaltic pyroclasts; (B2) explosive and effusive material; (B3) pyroclastic materials; (B4) thick basaltic flow; (B5) last volcanic stage.

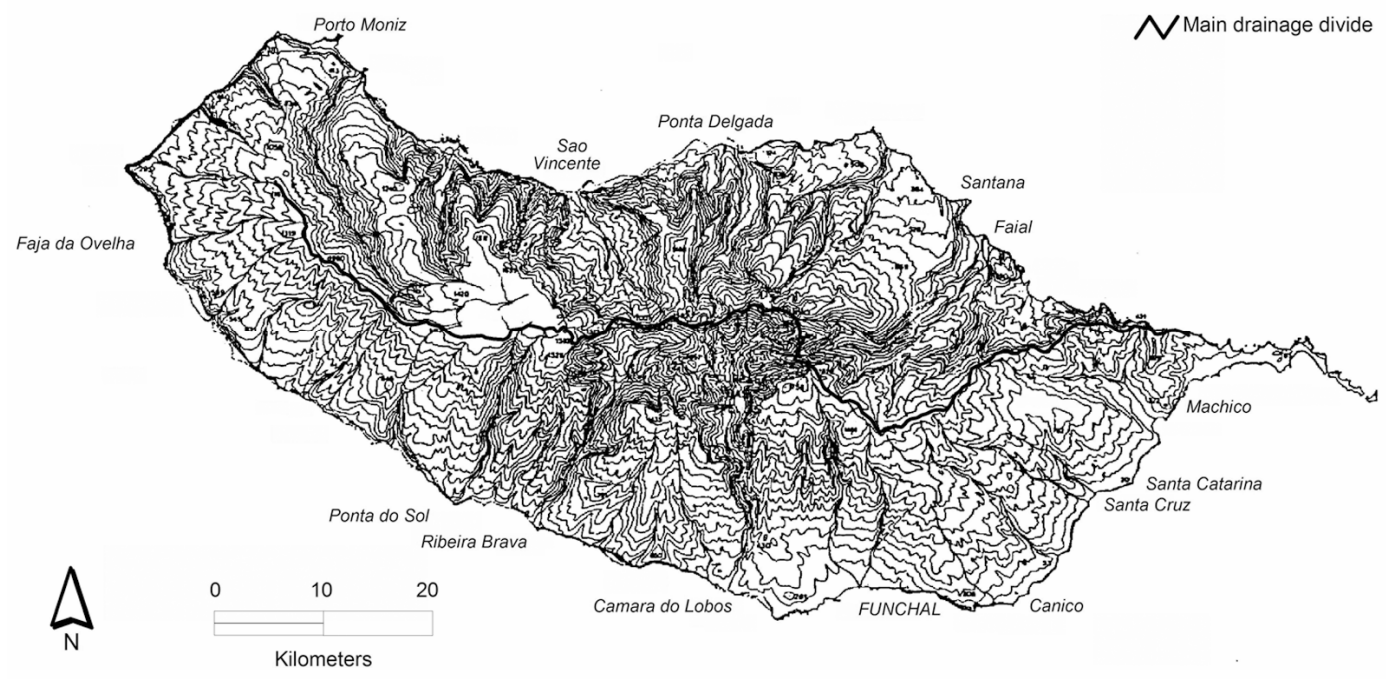

Fig. 3. Topography of Madeira Island (equidistance $100 \mathrm{~m}$.) modified by Galopim de Carvalho and Brandao, 1991.

in altitude, rising up abruptly from the sea. Relief increases in altitude from east to west, and the island's highest point is Pico Ruivo $(1860 \mathrm{~m})$. The areas above $1000 \mathrm{~m}$ represent approximately one-third of the entire area of the island $(\mathrm{Ga}-$ lopim de Carvalho and Brandao, 1991). The mountains act as an effective barrier between the north and south sides, giving them completely different climatic characteristics and different exposures to erosive agents.

Climatic conditions are fundamental in explaining the morphological differences between the northern and southern flanks of the island, because these two environments have a marked difference in exposure to the dominant northerly and northeasterly winds, to the consequent wave motion, and to rainfall.
According to many authors (Ribeiro, 1948; MichellThome, 1979; Wirthmann, 1970), the location of Madeira's main water catchment divide, which does not coincide with the median line of the island but lies further to the south, is proof of the rapid and more extensive erosion to which the north side is subjected. The interior valleys trend radially from the central mountain massif towards the coast influencing the hydrographic network, which is heavily incised, with an exceptionally direct trend (Michell-Thome, 1976; Czajkoski, 2002). The accepted view is that these valleys are purely erosional features, but according to some authors the straightness of the valleys is an indication of structural influences on their courses (Scheidegger, 2002). 
The most active geomorphic processes are coastal erosion, runoff erosion, chemical weathering of pyroclastic rocks, and landslide activity. The coast on the north side of the island has higher cliffs than the coast on the south side. Along the south coast, the slopes are more gentle and the cliffs are sometimes interrupted by beaches.

On this side of the island, intense human activity has caused further changes to the landscape, which will be described later.

\subsection{Climatic characteristics}

The climate of Madeira is determined mainly by the subtropical Azores anticyclone. During the summer, masses of tropical air reach Madeira, while in the winter, when the Azores anticyclone returns to its usual, more southerly position, Madeira is affected by the polar front from the North Atlantic. During the winter, between November and February in particular, Madeira benefits from the formation of an anticyclonic area opposite Morocco that affects the island's weather for a few weeks before dissipating (Caldera et al., 2002).

The topographical barrier formed by the main drainage divide in the center of the island creates a climatic difference between the southern and northern coasts, with much more pleasant conditions on the southern side (Caldera, 1996).

In general, Madeira's climate is surprisingly humid and temperate, considering its latitude, due to the effects of the surrounding ocean (Dias et al., 1992).

The annual average temperature varies significantly both with altitude and between the southern and northern sides, with typical values between $17^{\circ} \mathrm{C}$ and $19^{\circ} \mathrm{C}$, but descending as low as $9^{\circ} \mathrm{C}$ in the mountainous areas (Van der Weijden and Pacheco, 2003).

The annual precipitation on Madeira (Fig. 4) varies from $600-800 \mathrm{~mm}$ on the south coast to $1500-2000 \mathrm{~mm}$ on the north coast, reaching $3000 \mathrm{~mm}$ in the higher areas. The rainfalls are often violent with an intensity that can reach $500 \mathrm{~mm}$ in a single day (the maximum recorded is $522.3 \mathrm{~mm}$ ), especially in autumn and early spring when very high-intensity rainfalls occur within a very short time (sometimes no more than three hours) and are often associated with strong winds and stormy seas.

\section{Methodology of investigation}

A detailed analysis of damaging landslides and floods was carried out to determine their distribution in space and time, as well as possible variations in frequency and recent evolutionary trends.

For flood events, the data include frequency, geographic distribution, and damage caused.
For mass movements, the data include the classification, mechanism, frequency, geographic distribution, and damage recorded.

A georisk database (Rodrigues and Ayala-Carcedo, 2000) contains records for approximately 700 events from 1611 to the present, supplemented by additional data for the last few decades which were supplied by the regional institutions archive of Madeira. In the data as recorded, numerous attributes are often included for each individual event surveyed, such as the type of event, the location, the date, the meteorological conditions previous to the event, and the effects on the population and on structures.

The information does not refer only to catastrophic events but also includes events of lesser intensity, and when it is complete, it provides an excellent description of each individual event, particularly in the period from 1941 to 1991.

The database incorporates mainly the landslides and floods that have caused damage, and it allows the analysis of the evolution of the risk.

The usefulness of historical records in dating the occurrence of ancient and recent landslide events has been demonstrated by many authors (Garland and Oliver, 1993; Brunsden et al., 1995; Chandler and Brunsden, 1995; Ibsen and Brunsden, 1996), and many scientists all over the world have used written accounts or proxy data for the analysis of hazardous flood events (Barnikel and Becht, 2003; Barriendos et al., 2002; Coeur et al., 1998; Stedinger and Cohn, 1986; Sutcliffe, 1987).

Analysis of evolutionary trends in landslide and flood events and rainfall was carried out to verify whether climatic change is the only or the main cause of the increasing frequency of damaging landslides and floods on Madeira, or whether human factors have had a significant impact. Landslides and floods almost always occur during or immediately after intense rainfall, as is well documented from news and historical reports and the direct experience of the inhabitants.

After examination of the historical data on landslides and floods and climatic data for the entire island, an area located to the south of the main drainage divide of the island extending between Faja da Ovelha and Machico was selected for detailed study, because here the lithology (Fig. 2), topography (Fig. 3), and pluviometry (Fig. 4) reveal an area with highly uniform natural characteristics, which should enable the isolation of human influences.

This area includes two distinct zones. In the southeastern part, located between Camara da Lobos and Machico (21 drainage basins), human activity is intense. There are two main cities (Funchal and Machico), four smaller cities (Camara do Lobos, Canico, Santa Cruz, and Santa Catarina), and most of the economic and human activities on the island are located here. In the other area, located between Camara da Lobos and Faja da Ovelha (26 drainage basins), human activity is much less intense, and the only cities with increasing human activity are Ponta do Sol and Ribeira Brava. 


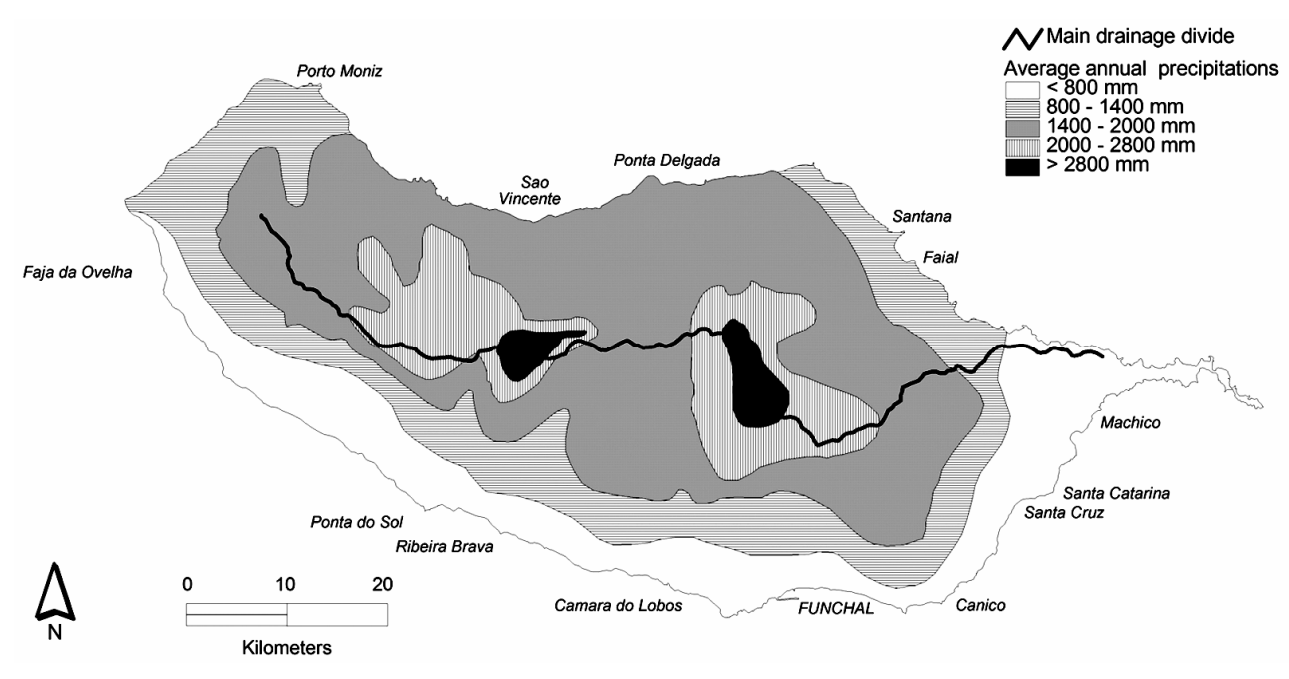

Fig. 4. Average annual precipitation in Madeira Island (historical records 1961-1990). Image (modified) from Ministero do Ambiente e do ordenamento do Territorio of Portugal website.

The final phase of this investigation involved documentation of modifications introduced directly and indirectly as a result of human activity that might encourage the occurrence of landslides and floods.

\section{Results}

\subsection{Analysis of historical data for damaging landslide and flood events}

Historical data from 1611 to the present show clearly that the hazardous events that have had the greatest impact and that have produced the worst damage are "flash floods", followed by landslide events.

\subsubsection{Extreme events}

Considering extreme events (landslides and floods) that can be characterized as natural disasters (Alcantara-Ayala, 2002; Blaikie et al., 1994), the data show that: (i) only one event is recorded in the eighteenth century (a flash flood in November 1724, with 26 deaths and 80 homes damaged in the city of Machico); (ii) two events are recorded in the nineteenth century (a flash flood in 1803 with approximately 600 deaths, the worst calamity ever recorded in the history of Madeira, and another flash flood in 1842 with one death and the destruction of a large part of the city of Funchal); (iii) six events are recorded in the twentieth century (a flash flood in 1920 with two deaths and 500 people left homeless; a debris flow in 1929 with 34 deaths; a flash flood in 1956 with six deaths; another flash flood and debris flow in 1979 with 14 deaths; a flash flood in 1993 with seven deaths and 47 injured; an earth flow in 1997 with 20 homes destroyed).
These data reveal that: (i) in the twentieth century, the number of the most serious catastrophic events and the cost of the damages caused increased substantially with respect to the two previous centuries; (ii) the twentieth century events are concentrated in the second half of that century (four events out of six occurred between 1956 and 1997); (iii) the interval between events became shorter and shorter (higher frequency of catastrophic events).

The new century does not appear to have changed this trend. In fact, two extreme events have already been recorded.

On 5-6 March 2001 after intense rain, disastrous events caused the death of five people as well as damage amounting to 50 million USD. In the area of Rosario, two debris flows damaged a main road, sweeping away a car containing four tourists and killing them as well as damaging countless homes and a school; in the city of Curral, a debris flow occurred, submerging several homes. Because these events occurred during the day, sufficient time was available to raise the alarm and to evacuate many people from the most dangerous areas, thus avoiding a tragedy of even greater proportions (Rodrigues and Ayala-Carcedo, 2003).

On 20 February 2010, after heavy rain, a flash flood and mudslide occurred in Funchal where the streets were littered with debris and coated with mud. Some residents had to hold on to railings or any sturdy object they could find so they weren't swept away by the torrents. A number of cars were caught by the force of the water, and the battered shells of overturned vehicles littered the streets. The disastrous events caused the death of forty-two people, more than 120 people were injured, and displaced more than two hundred people. The damage amounted to about 1.4 billion of Euro. 


\subsubsection{Landslides}

This investigation indicated that: (i) the landslides surveyed could be classified as debris flows, mudflows, earth flows, or rock fall, using the Varnes classification (Varnes, 1978); (ii) landslide frequency increased (decreased interval between recurrences) during the study period; (iii) between 1941 and 1991, 596 landslides were recorded on the island; 262 events occurred in the south sector (47 drainage basins, surface area of $314.01 \mathrm{~km}^{2}, 0.834$ landslides $\mathrm{km}^{2}$ ), and 334 events occurred in the remaining northern sector (40 drainage basins, surface area of $424.99 \mathrm{~km}^{2}, 0.786$ landslides $\mathrm{km}^{2}$ ); (iv) although the increase in observed frequency is quite widespread, the data appear to indicate that the frequency of occurrence in the southeastern part of Madeira is above average; (v) most events occur between the months of November and April; (vi) rainfall is the main cause of the landslides.

\subsubsection{Floods}

The data reveal that: (i) flood events are mainly flash floods; (ii) there is an increase in frequency (decrease in the interval between events) over the study period; (iii) between 1941 and 1991, a total of 56 damaging events were recorded in all 87 drainage basins of the island; 46 events occurred in the sector to the south of the island's main drainage divide, and only 10 events occurred in the sector to the north of the island's main drainage divide; (iv) in the northern sector, events occurred in only three drainage basins, and 8 out of a total of 10 events occurred in the drainage basins that are subjected to some human activity (four in the Sao Vicente basin, four in the Fajal basin); (v) in the southern sector, events occurred in 11 drainage basins, and 31 out of a total of 46 events occurred in the southeastern sector; (vi) a completely different incidence frequency was observed for the events recorded in the two sectors separated by the island's main drainage divide. This observation reveals a difference in susceptibility to flooding, which arises from the climatic conditions and the rainfall data for the two sides of Madeira Island.

\subsubsection{Sector to the south of Madeira's main drainage divide}

The data for landslide events that occurred between 1941 and 1991 (illustrated in Fig. 5) reveal that: (i) 182 landslides $(69.5 \%)$ occurred in the southeastern sector between Camara da Lobos and Machico and 80 in the remaining southwestern sector; (ii) the areas with the highest number of landslides correspond to the drainage basins where the main urban centers are located, that is, in the southeastern sector, the capital, Funchal (84 events), Santa Cruz (23 events), and Machico (24 events), and in the southwestern sector, Ponta do Sol (23 events) and Ribeira Brava (29 events). The remaining parts of the territory, which are not so intensely affected by human activity, have much fewer landslide occurrences.
The data for floods that occurred between 1941 and 1991 (Fig. 5) reveal that: (i) out of a total of 46 events recorded and located within 11 drainage basins, 31 (67.4\%) occurred in the southeastern area between Camara do Lobos and Machico, while 15 events occurred in the remainder of the southwestern sector; (ii) the areas with the most floods are those drainage basins where the main urban centers are located, that is, in the southeastern sector, the capital, Funchal (17 events), Santa Cruz (4 events), and Machico (5 events), and in the southwestern sector, Ponta do Sol (6 events) and Ribeira Brava (7 events).

The integrated analysis of landslide and flood data for this sector shows that: (i) there was a significant difference in values between the southeastern and southwestern sectors for the total number of all hazardous events (landslides and floods) and for event density (expressed as number of events per $\mathrm{km}^{2}$ and referred to below as the density of damaging events, or NHD). In the southeastern area between Camara da Lobos and Machico, 213 events $(72.7 \%)$ were recorded, with an average NHD value of 1.66 , as opposed to 95 events and an average NHD value of 0.51 for the southwestern area between Camara da Lobos and Faja da Ovelha; (ii) in the southeastern area, the highest values were recorded in the areas of Machico (29 events with an NHD of 1.34), Santa Catarina (14 events with an NHD of 2.36), Santa Cruz (27 events with an NHD of 097), Canico (17 events with an NHD of 1.47), Camara do Lobos (20 events with an NDE of 1.21), and in the area of the capital, Funchal, with the highest values in the entire southern part of the island (101 events with an NHD of 2.46); (iii) in the southwestern area, the highest values were recorded in the areas of Ponta do Sol (29 events with an NHD of 1.33) and Ribeira Brava (36 events with an NHD of 0.88); (iv) the areas where human activity is greatest have a number of occurrences of damaging landslides and floods that is 2.7 times higher than that of less-disturbed areas, and a density of damaging events which is up to four times higher.

\subsection{Analysis of rainfall historical data}

Recorded data for the twentieth century show that: (i) rainfall is concentrated in the period between October and April, during which time $90 \%$ of the annual precipitation is recorded; (ii) annual rainfall has not been increasing over time; on the contrary, rainfall has been decreasing progressively since the beginning of the twentieth century; (ii) there are no significant decadal oscillations in annual rainfall; (iii) there has been no increase in the annual number of high-intensity and high-magnitude rainfall events.

Rainfall data from 1941 to 1991 recorded at the Santa Catarina station near the airport (Fig. 6) reveal that: (i) the average annual rainfall value is $681.4 \mathrm{~mm}$, and the maximum value is $1236.0 \mathrm{~mm}$ (recorded in 1968), and the minimum value is $387.4 \mathrm{~mm}$ (recorded in 1947); (ii) the annual rainfall (Fig. 6a) shows a modest increasing trend from 1941 to 


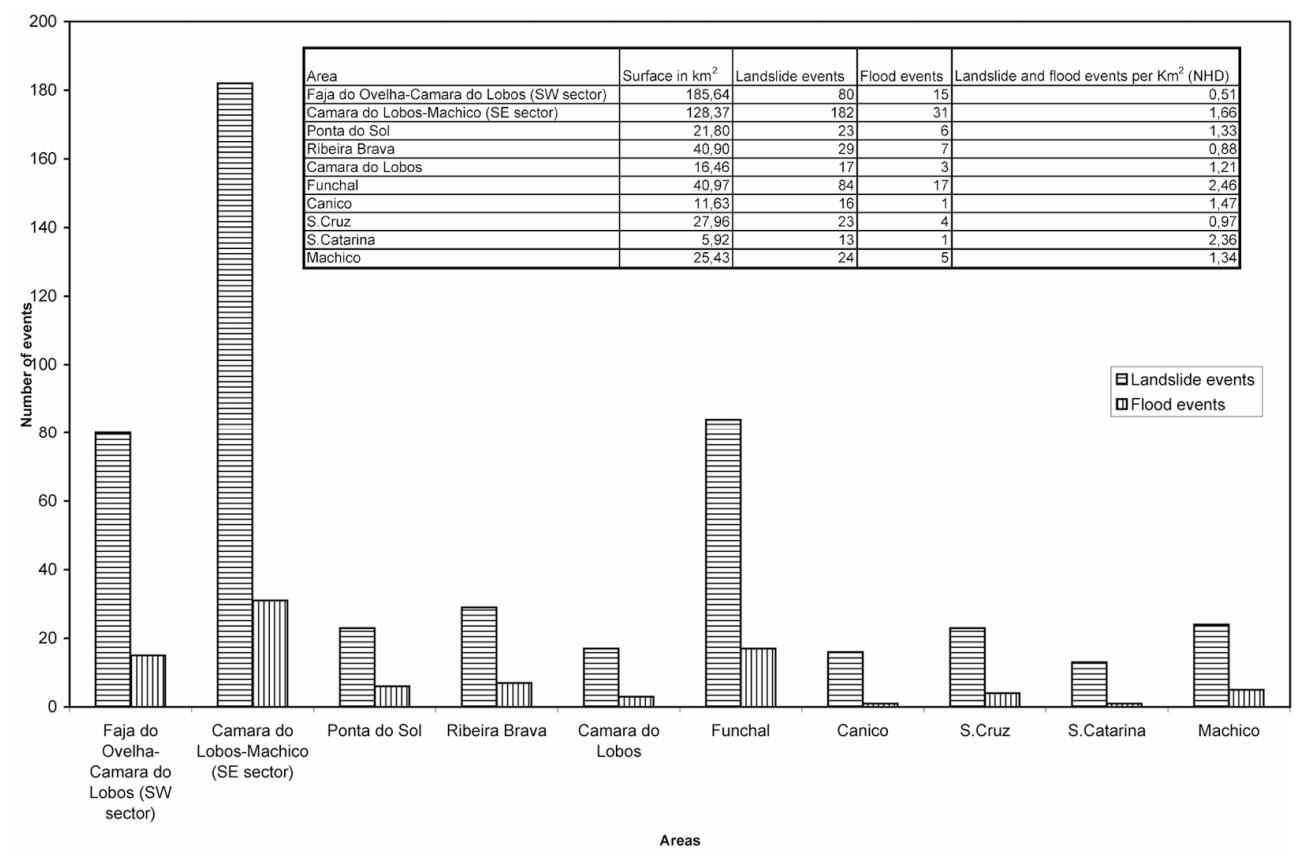

Fig. 5. Distribution of landslide and flood events that occurred in the period 1941-1991 in the sector of the island located to the south of the main drainage divide and in the main urban areas. The table also indicates the density of damaging events (NHD) expressed as number of events per $\mathrm{km}^{2}$.

1969 and then a decreasing trend from 1970 to 1991; (iii) the total rainfall for the period between October and April for each year (Fig. 6b) shows an increasing trend for the period from 1941/1942 to 1960/1961, followed by stable values during the period 1962/1963-1973/1974 and a decreasing trend for the period 1974/1975-1990/1991, which has become more evident since the 1978-1979 season; (iv) the number of months for each year with different classes of rainfall values (over $50 \mathrm{~mm}$ (Fig. 6c); $100 \mathrm{~mm}$ (Fig. 6d); $200 \mathrm{~mm}$ (Fig. 6e); and $300 \mathrm{~mm}$ (Fig. 6f)) shows no significant variation for the lowest class (number of months with rainfall higher than $50 \mathrm{~mm}$ ) and decreasing trends over time for all the other classes. The data also show no significant variation in the number of high-intensity and high-magnitude rainfall events.

\subsection{Modifications caused by human activity}

Field observations were made during an entire winter from October 2000 to April 2001.

The principal factors leading to mass earth movements seem to be: (i) the exposure of bare ground by deforestation and mining; (ii) reduction of water infiltration by the expansion of uncontrolled urbanization and rapid construction of buildings and roads. The principal factors leading to flood phenomena seem to be: (i) the channeling of rivers in combination with urbanization; (ii) increasing encroachment of development in flood plain areas.
The changes introduced by human activity were grouped into the following main classes:

\subsubsection{Urbanization}

Urbanization on Madeira has expanded to use all of the space available. The shortage of space has forced new construction onto riverbanks; this has brought about the constriction and occupation of river mouths (in particular those that cross the cities of Funchal and Machico which have become major new construction zones), and led to the occupation of the flood plains.

In particular, the urbanization of the flood plain areas of the main rivers without regard to past peak flow stages may cause property damage that could be avoided, an example of which can be found in the city of Machico (Fig. 7) which has experienced recent urbanization in an area earlier affected by a catastrophic flood.

Urban development in coastal areas, in particular in the urban centers like Funchal and Machico, has also occurred along the coastline, occupying beaches and clifftop areas.

To create flat areas for home and footpath construction, slopes have been excavated and lateral support removed (Fig. 8) by digging away part of the steep slopes. The phenomenon of decreased hill slope stability due to excavation is well known in Machico, where excavation for house construction has been the main triggering cause for slope failure and creep movement. 


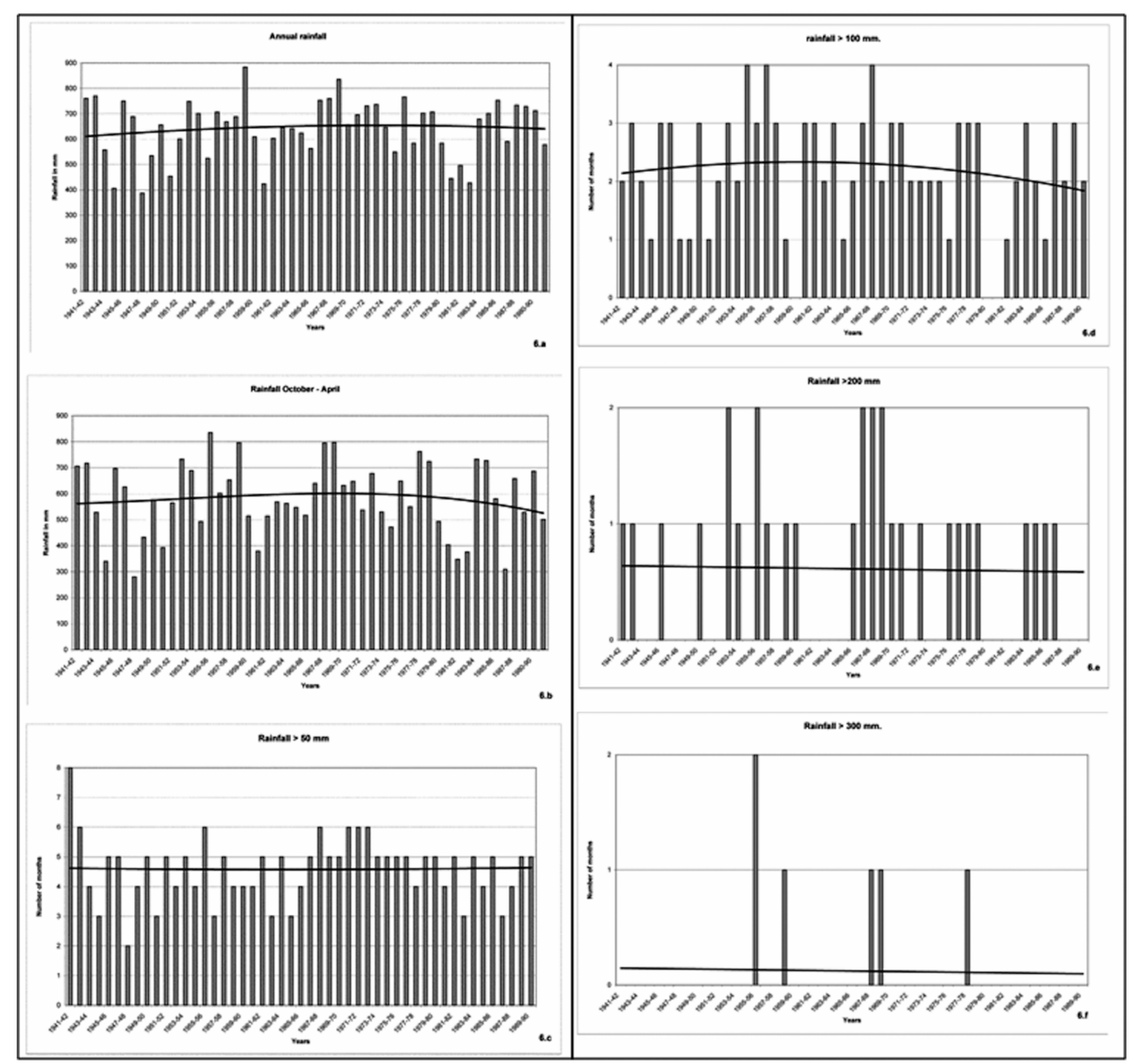

Fig. 6. Rainfall recorded in Santa Catarina for the period 1941-1991; annual values (a); total values for the period October-April for each year (b); number of months with rainfall over $50 \mathrm{~mm}$. (c); number of months with rainfall over $100 \mathrm{~mm}$. (d); number of months with rainfall over $200 \mathrm{~mm}$. (e); number of months with rainfall over $300 \mathrm{~mm}$. (f).

The construction of buildings and roads on slopes promotes the development of gully systems, which in turn increases sediment load in the drainage network.

The expansion of cities and the construction of bridges and roads have increased the area covered by impermeable surfaces, raising the runoff coefficient; this has led in turn to a more rapid concentration of runoff, with a consequent increase in the magnitude of flash floods.

\subsubsection{Drainage and river systems}

The interventions which have been carried out on the waterways of the island are easily recognizable and represent one of the most obvious examples of human-caused changes in the landscape. Works carried out on the beds of the main rivers to create sites suitable for building have drastically changed the characteristics of the rivers.

The initial impact of building activity along the riverbanks was a change in meander pattern. In the main rivers, some projects changed the fluvial morphology by narrowing the original riverbeds and reducing the original section, and altering the length of the natural riverbeds through channeling and shaping of the original routes. The resulting artificial canals have a continuous vertical wall of cement on the outside.

The result of these modifications has been an increase of peak flow discharge, which increases the erosion of riverbanks, which then becomes a potential hazard. The modifications also reduce the bed roughness and increase flow velocity, increasing the occurrence of floods.

Human activity has also produced changes in the surface drainage system, resulting in the creation of anomalous waterways. In urban areas, especially in the new areas located behind the coastal strip of Funchal, Machico, and Ponta do Sol, diversion of surface runoff as a result of building and road construction has created network branches characterized by anomalous patterns such as elbow and rectilinear segments.

An example of heavy modification of the drainage system can be found in the city of Ponta do Sol (Fig. 9) where along 

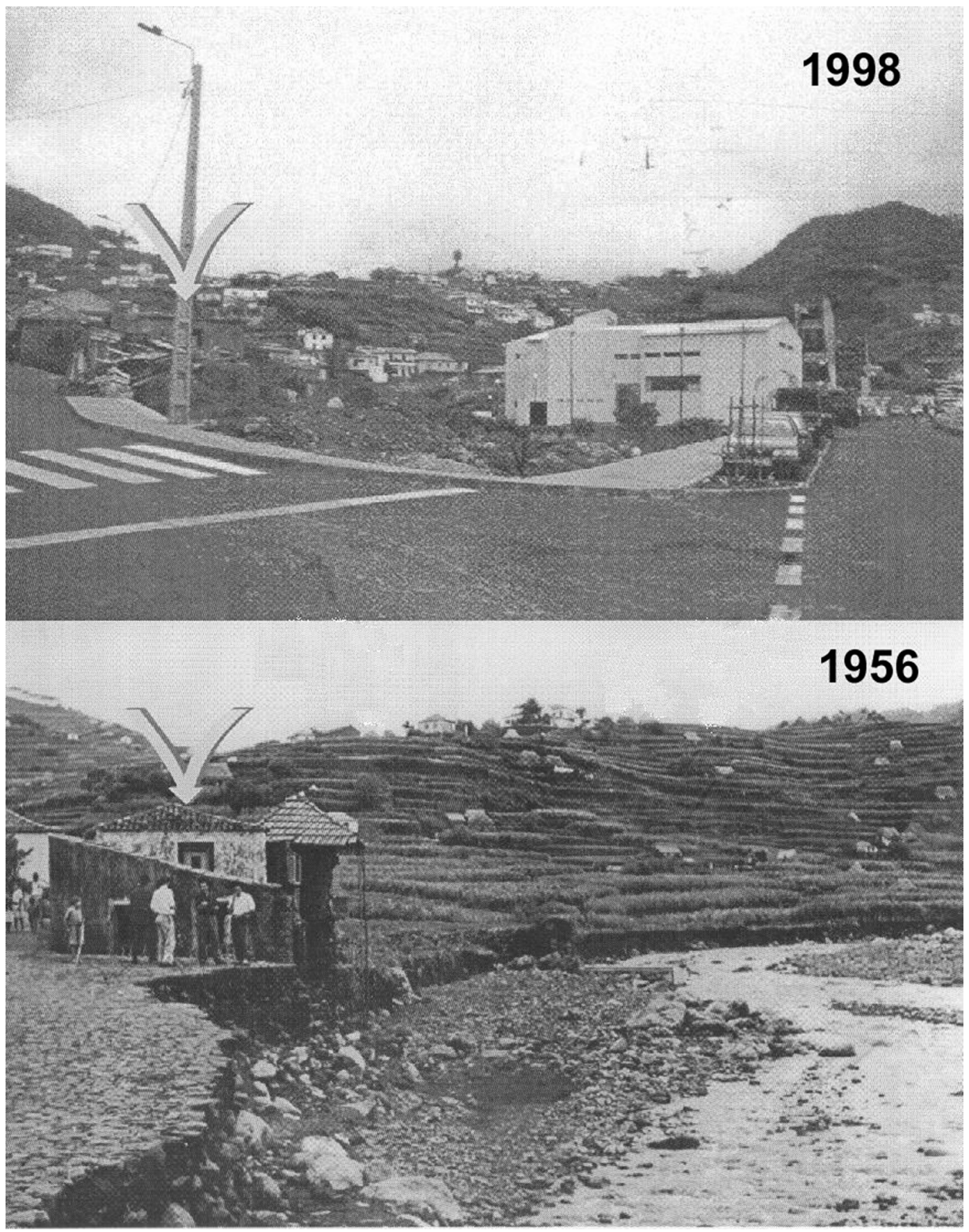

Fig. 7. City of Machico: the same area (white arrow indicate the same building) during the flood occurring in 1956 and after the construction of the local fireworks station building (white building) in 1998. Image courtesy of Domingos Rodrigues (Madeira University).

the course of the main river (Ribeira do Ponta do Sol), human activity has brought about: (i) a change in the original route through the creation of an artificial elbow, (ii) a reduction of the original size of the riverbed and its replacement by artificial canals, and (iii) occupancy of the riverbed by houses.

\subsubsection{Land use}

The main cause of land use change has been the reduction in forest cover in mountainous areas by deliberate fires and by deforestation to obtain land suitable for sheep farming. Deforestation and ill-advised grazing lead to the degradation of the land due to progressive elimination of plant cover, thus 


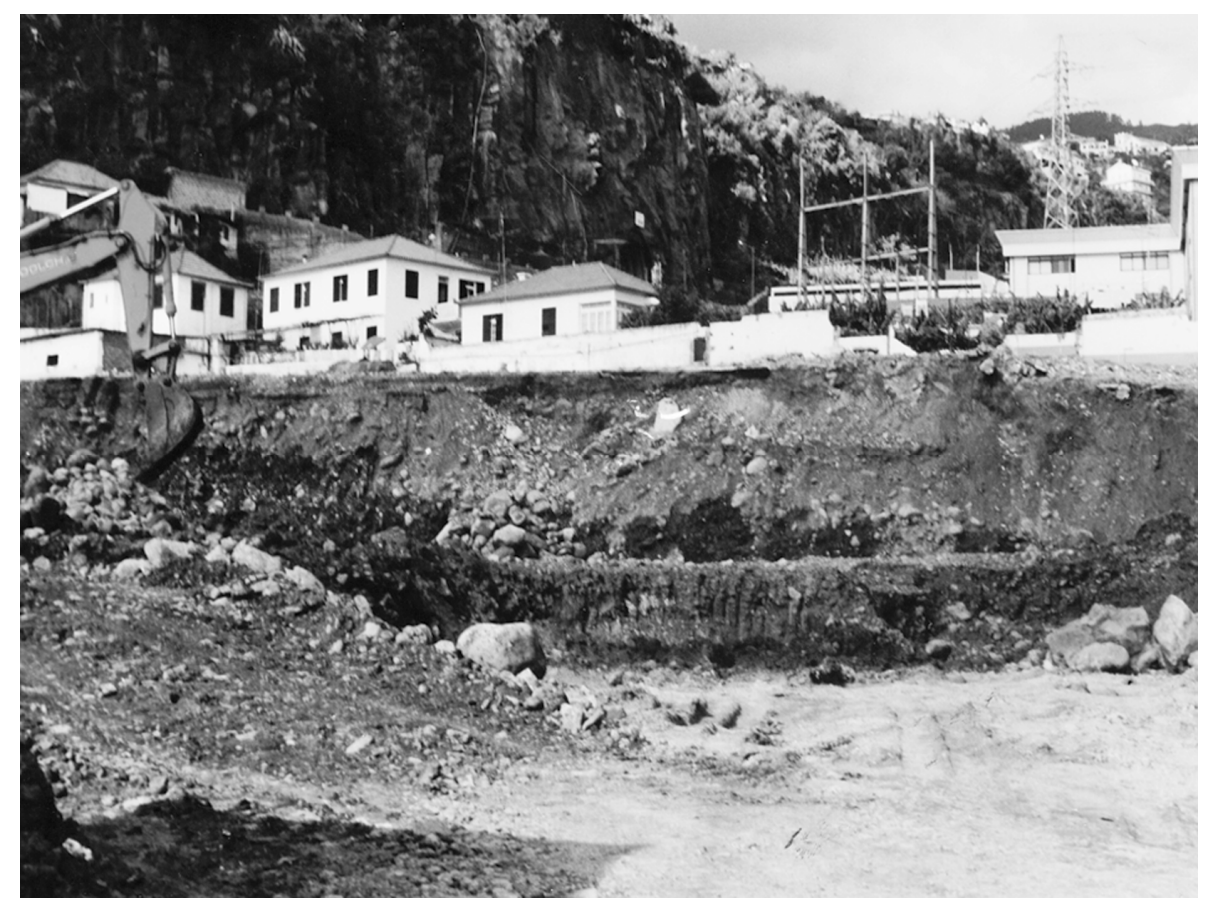

Fig. 8. City of Funchal: excavation works to make a new building area removing the support of the area already built (image taken by the author).

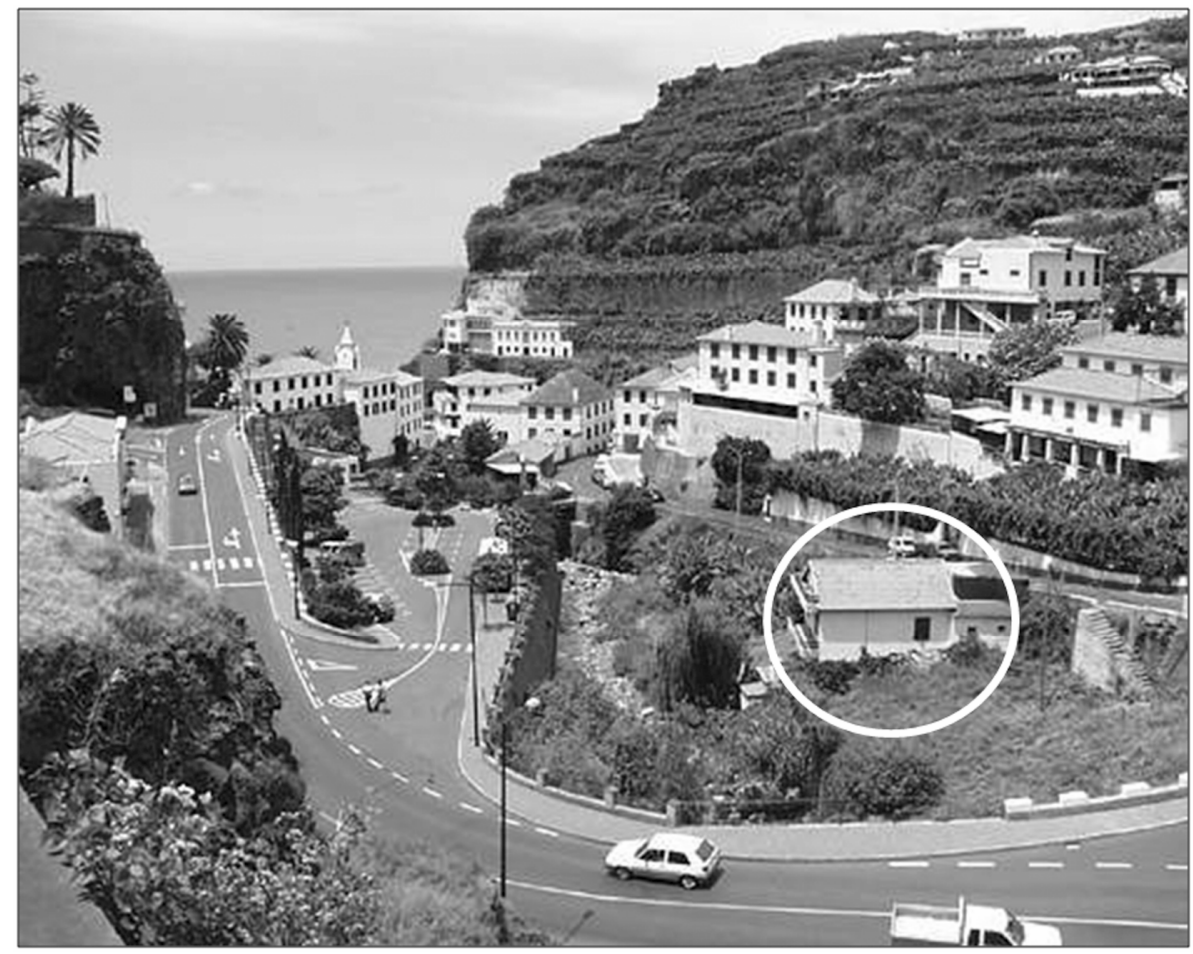

Fig. 9. City of Ponta do Sol: artificial elbow of the course of the "Ribeira do Ponta do Sol" built in the upper part of the city; inside the artificial riverbed a house is located (white circle). Image courtesy of Domingos Rodrigues (Madeira University). 
favoring the occurrence of accelerated erosion phenomena, the main cause of landslides (Alexander, 1993).

In fact, the absence of landslides under forest on slopes with topographic and lithology characteristics similar to known landslide sites is an indicator of the importance of forest cover on Madeira.

In the last two decades, there has also been a progressive abandonment of farming on Madeira. The cultivated surface area decreased about $20 \%$ from 1986 to 1991, and nowadays cultivation is limited to very localized favorable areas.

\section{Discussion and conclusions}

The chronology of damaging landslide and flood events shows a progressive increase in the frequency of similar and comparable events from the past into the present.

The data reveal that most events occur in the period between November and April; during the same period, almost all the annual rainfall occurs, which clearly suggests that the main factor triggering the occurrence of landslides and floods is the rainfall (regarding landslide events, there are no recorded cases of phenomena that occurred following seismic movement).

This study indicates rather that: (i) there is a geographical correspondence between the incidence of damaging landslides and floods and associated human activity on Madeira. In fact, the increase in landslides and floods occurs mainly in the areas with intensified human activity, particularly in the southeastern sector which has the lowest rainfalls and the most human activity; (ii) there seems to be no relationship between the observed increase in damaging landslides and floods and any trends in rainfall; (iii) much of the impact of human activity in the form of land cover changes, diversion of surface runoff, and related variations in saturated and unsaturated layer conditions may have increased the sensitivity of the surface layer to triggering factors (rainfall), producing a related geomorphic response (landslides and floods).

This evidence would suggest that (i) on Madeira Island, there is a direct relationship between the modifications to the landscape introduced by human activity and the observed increase in damaging landslide and flood events; (ii) the increase over time and in geographic extent of damaging landslides and floods seems to have been caused by an increase in the magnitude and frequency of these human interventions and by the resultant rapid increase in exposure and vulnerability of the landscape, and consequently an increase of the risk (Blaikie et al., 1994); both factors seem to be related to human activity rather than to climatic factors, as a consequence of human modifications to the landscape in the course of recent human development.
Acknowledgements. I gratefully acknowledgements the assistance and the help of my friend Domingos Rodrigues (Madeira University) during my trips and stay in Madeira and to provide me useful images and data for this paper. Many thanks to Ms. Sabrina Palleri to provide me the funds to publish this paper. This paper is dedicate to Piia Elina Askolin.

Edited by: D. Castaldini

Reviewed by: C. Cencetti and another anonymous referee

\section{References}

Alcantara-Ayala, I.: Geomorphology, natural hazards, vulnerability and prevention of natural disasters in developing countries, Geomorphology 47, 107-124, 2002.

Alexander, D. E.: Natural Disasters, UCL Press and Chapman \& Hall, London and New York, 279 pp., 1993.

Barnikel, F. and Becht, M.: A historical analysis of hazardous events in the Alps - the case of Hindelang (Bavaria, Germany), Nat. Hazards Earth Syst. Sci., 3, 625-635, doi:10.5194/nhess-3625-2003, 2003.

Barriendos, M., Coeur, D., Lang, M., Llasat, M. C., and Naulet, R.: Stationary analysis of historical floods in France and Spain, with a classification of events based on historical flood levels or damage. Geophysical Research Abstract 4, Abstract of the contributions of the 27th General Assembly of the European Geophysical Society, Nice, France, 21-26 April, 2002.

Blaikie, P. P., Cannon, T., Davis, I., and Wisner, B.: At risk: natural hazards, people's vulnerability, and disasters, Routledge, London, 320 pp.,1994.

Brunsden, D., Ibsen, M. L., Lee, M., and Moore, R.: The validity of temporal archive records for geomorphological processes, Quaestiones Geographicae, 4, 79-91, 1995.

Caldera, R. M. A.: ASOMIR (Applications of Space Oceanography in the Madeira Island Region), MS project, Institute of Marine Studies, University of Plymouth, 1996.

Caldera, R. M. A., Groom, S., Miller, P., Pilgrim, D., and Nezlin, N. P.: Sea-surface signatures of the island mass effect phenomena around Madeira Island, Northeast Atlantic, Remote Sens. Environ., 80, 336-360, 2002.

Chandler, J. H. and Brunsden, D.: Steady-state behavior of the Black Ven mudslide: the application of archival analytical photogrammetry to studies of landform change, Earth Surf. Proc. Land., 10, 225-275, 1995.

Coeur, D., Lang, M., Naulet, R., Burnet, R. and Strazzeri, D.: Histoire et connaissances des phénomènes naturels extrêmes, Ingénières-EAT, Special issue, 15-26, 1998.

Czajkoski, M.: A geological tour of the islands of Madeira and Porto Santo, Geology Today, 18, 26-34, 2002.

Dias, C. M., Amorim, A., and Vacas, M. D.: Sea surface temperature: seasonal variation between the Iberian coast and the Madeira Islands 1981-1987, ICES Marine Science Symposium, 195, 177-186, 1992.

Galopim de Carvalho, A. M. and Brandao, J.: Geologia do arquipelago da Madeira. Museu nacional de historia natural Università de Lisboa, Lisbon, 1-154, 1991.

Garland, G. and Oliver, M.: Predicting landslides from rainfall in a humid, subtropical region, Geomorphology 8, 165-173, 1993. 
Geldmacher, J. and Hoernle, K.: The 72 Ma geochemical evolution of the Madeira hotspot (eastern North Atlantic): Recycling of Paleozoic (500 Ma) ocean crust, Earth Planet Sci. Lett., 183, 7392, 2000.

Ibsen, M. L. and Brunsden, D.: The nature, use and problems of historical archives for the temporal occurrence of landslides, with specific reference to the 67 south coast of Britain, Ventnor, Isle of Wight, Geomorphology, 15, 241-258, 1996.

Michell-Thome, R. C.: Geology of the middle Atlantic islands, Borntraeger, Berlin, 382 pp., 1976.

Michell-Thome, R. C.: Notes on the geomorphology of Madeira, Bol. Mus. Munic. Funchal, 32, 5-18, 1979.

Ribeiro, O.: Notulas de geomorfologia madereinse, Bol. Soc. Geol. Portugal, 7, 113-118, 1948.

Rodrigues, D. and Ayala-Carcedo, F.: Georisk: A natural hazard database of historic events in Madeira Island, 25th General Assembly EGS, Nice, 286 pp., 2000.

Rodrigues, D. and Ayala-Carcedo, F.: Rain-induced landslides and debris flows on Madeira Island, Portugal, Landslide News, 1415, 43-45, 2003.
Scheidegger, A. E.: Morphometric analysis and its relation to tectonics in Macronesia, Geomorphology 46, 95-115, 2002.

Stedinger, J. R. and Cohn, T. A.: Flood frequency analysis with historical and paleoflood information, Water Resour. Res., 22-5, 785-793, 1986.

Sutcliffe, J. V.: The use of historical records in flood frequency analysis, J. Hydrology, 96, 159-171, 1987.

Varnes, D. J.: Slope movement types and processes, in: Landslide Analysis and Control, edited by: Schuster, R. L. and Krizek, R. J., Transportation Research Board Special Report, 176, National Research Council, Washington DC, 11-33, 1978.

Van der Weijden and C. H. and Pacheco, F.: Hydrochemistry, weathering, and weathering rates on Madeira Island, J. Hydrol., 283, 122-145, 2003.

Wirthmann, A.: Zur klimageomorphologie von Madeira und anderen Atlantikinseln, Karlsruher Geographische Hefte 2, Karlsruhe, 56 pp., 1970.

Zbyszewski, G., Ferreira, O. V., Medeiros, A. C., Aires Barros, L., Silva, L. C., Munha, J., and Barriga, F.: Noticia explicativa das folhas A e B da ilha da Madeira. Carta Geologica de Portugal na escala 1/50000, Servicos Geologicos de Portugal, Lisbon, 1975. 